\title{
Phanerogamic flora and phytogeography of the Cloud Dwarf Forests of Ibitipoca State Park, Minas Gerais, Brazil
}

\author{
Breno Moreira $^{1 *}$ (), Fabrício Alvim Carvalho ${ }^{2}$, Luiz Menini Neto ${ }^{2}$ \& Fátima Regina Gonçalves Salimena ${ }^{2}$ \\ ${ }^{1}$ Universidade Federal de Juiz de Fora, Programa de Pós Graduação em Ecologia, Campus Universitário, Rua \\ José Lourenço Kelmer, s/n, Martelos, 36036-330, Juiz de Fora, MG, Brasil \\ ${ }^{2}$ Universidade Federal de Juiz de Fora, Departamento de Botânica, Campus Universitário, Rua José Lourenço \\ Kelmer, s/n, Martelos, 36036-330, Juiz de Fora, MG, Brasil \\ *Corresponding author: Breno Moreira,e-mail: biomota2009@hotmail.com
}

MOREIRA, B.; CARVAlHO, F. A.; MENINI NETO, L.; SALIMENA, F. R. G. Phanerogamic flora and phytogeography of the Cloud Dwarf Forests of Ibitipoca State Park, Minas Gerais, Brazil. Biota Neotropica. 18(2): e20170506. http://dx.doi.org/10.1590/1676-0611-BN-2017-0506

\begin{abstract}
This study was developed in Ibitipoca State Park (ISP), a mountainous massif that stands out in the Serra da Mantiqueira, in the Southeastern Region of Brazil. The vegetation is represented by a phytophysiognomic mosaic where areas of campos rupestres interspersed with cloud dwarf forests predominate, at altitudes of 1100 to 1700 m.s.m. The cloud dwarf forests exist in narrow altitude belts on the mountain peaks, immersed in a layer of clouds. They form a peculiar landscape high in the mountains by the short stature of the arboreal elements and richness of lichens and bryophytes, which develop under constant condensation of humidity, low temperatures, and frequent winds. The objective of the present work was to determine the floristic composition and phytogeography of the cloud dwarf forests of ISP. Twelve monthly campaigns were conducted to collect botanical material during the years 2014 and 2015. The collected material was deposited in the collection of the CESJ Herbarium. A total of 372 species, 209 genera, and 73 families of phanerogams were found. The richest families were Orchidaceae ( $84 \mathrm{spp}$.), Asteraceae (39 spp.), and Melastomataceae (21 spp). The genera with the greatest wealth were Leandra (09 spp.), Epidendrum (09 spp.), Pleurothallis (09 spp.), Mikania (07 spp.), and Miconia (07 spp). The arboreal habit was predominant with 103 species (27.7\%), followed by 83 shrubs (22.3\%), 82 epiphytic herbs (22\%), 80 terrestrial herbs (21.5\%), and 23 lianas (6.5\%). The floristic composition presents elements typical of altitude vegetation, including species of campos rupestres and high epiphytes richness, especially of the families Orchidaceae and Bromeliaceae. The genera with tropical distribution represent $86.5 \%$, whereas the temperate elements represent $13.5 \%$ of the total. The cloud dwarf forests presented similarity, at the family and gender levels, with the upper montane forests of the Andes, besides phytogeographic characteristics that allow to associate them to a transition environment between the campos rupestres and the upper montane forests of the Southeast Region of Brazil.
\end{abstract}

Keywords: Atlantic Forest, cloud forest, conservation, dense ombrophylous forest, Serra da Mantiqueira.

\section{Flora fanerogâmica e fitogeografia das Nanoflorestas Nebulares do Parque Estadual do Ibitipoca, Minas Gerais, Brasil}

Resumo: Este estudo foi desenvolvido no Parque Estadual do Ibitipoca (PEIB), um maciço montanhoso que se destaca na Serra da Mantiqueira, na Região Sudeste do Brasil. A vegetação é representada por um mosaico fitofisionômico onde predominam áreas de campos rupestres entremeadas às Nanoflorestas Nebulares, em altitudes de 1100 a 1700 m.s.m. As Nanoflorestas Nebulares ocorrem em cinturões de altitude estreitos, nos picos de montanhas, imersas na camada de nuvens. Formam uma paisagem peculiar no alto das montanhas, pela baixa estatura dos elementos arbóreos e riqueza de líquens e briófitas, que se desenvolvem sob constante condensação de umidade, baixas temperaturas e ventos freqüentes. O presente trabalho teve como objetivo conhecer a composição florística e fitogeografia das Nanoflorestas Nebulares do PEIB. Foram realizadas 12 campanhas mensais para coleta de material botânico, durante os anos de 2014 e 2015. O material coletado foi depositado na coleção do Herbário CESJ. Foram encontradas 372 espécies, 209 gêneros e 73 famílias de fanerógamas. As famílias de maior riqueza foram Orchidaceae (84 spp.), Asteraceae (39 spp.) e Melastomataceae (21 spp). Os gêneros com maior riqueza 
foram Leandra (09 spp.), Epidendrum (09 spp.), Pleurothallis (09 spp.) Mikania (07 spp.) e Miconia (07 spp). O hábito arbóreo foi predominante, com 103 espécies (27,7\%), seguido por 83 arbustivas (22,3\%), 82 ervas epífitas (22\%), 80 ervas terrestres $(21,5 \%)$ e 23 lianas (6,5\%). A composição florística apresenta elementos típicos de vegetação de altitude, incluindo espécies de campos rupestres. Destaque para a alta riqueza de epífitas, especialmente das famílias Orchidaceae e Bromeliaceae. Os gêneros com distribuição tropical representam 86,5\%, enquanto os elementos temperados representam $13,5 \%$ do total. As Nanoflorestas Nebulares apresentaram similaridade, em nível de família e gênero, com as florestas montana e altmontana dos Andes, além de características fitogeográficas que permitem associá-las a um ambiente de transição entre os campos rupestres e as florestas altomontanas da Região Sudeste do Brasil.

Palavras-chave: Conservação, Floresta Atlântica, Floresta Nebular, Floresta Ombrófila Densa, Serra da Mantiqueira.

\section{Introduction}

The regions of tropical mountains are considered of great importance for the conservation of natural resources, presenting high biological diversity and a high index of endemism, propitiated by the variety of environments associated with biotic and abiotic factors that provide places favorable to speciation (Martinelli 2007). These regions represent refuges and corridors for regional and continental migrations, and often have richer plant diversity than the adjacent lowlands (Martinelli 2007). Nevertheless, little is known about the ecology, biogeography, and natural history of these formations, which have unique physiognomic characteristics (Körner 1999).

The upper montane vegetation in the Southeastern Region of Brazil is constituted by a vegetative mosaic composed by forest and field formations, which vary according to the geographic region and the altitude gradients (Oliveira-Filho 2009). Changes in floristic composition related to altitudinal gradients are strongly influenced by local environmental variables, since different altimetric heights have different temperature conditions, air humidity, water availability, exposure to winds, and classes of depth and soil drainage (Rahbek 2005, Grytnes \& McCain 2007, Slik et al. 2010). The increase in altitude and topographic irregularity in mountainous environments can decisively influence the heterogeneity of landscapes, interfering in the circulation of masses of air and exposure to the sun rays (Webster 1995). The influence of altitude on species diversification is complex. It is believed that the decrease in atmospheric pressure and temperature, as well as the increase in wind speed and solar radiation, may be related to high plant diversity (Körner 1999, Rahbek 2005).

The Serra da Mantiqueira is one of the largest and most important mountain chains in the Southeastern Region of Brazil (Almeida \& Carneiro 1998). It houses more than half of the endangered species of the fauna of Minas Gerais, with an expressive endemism of plant species (Costa \& Herrmann 2006). It extends from the Caldas Plateau and the Campos do Jordão Plateau in the south of Minas Gerais, a border with São Paulo, to the Plateau of Caparaó, on the border between Minas Gerais and Espírito Santo, with an approximate area of $13,176 \mathrm{~km}^{2}$ (Moreira \& Camelier 1977, Almeida \& Carneiro 1998). These mountain ranges have rocks dating from the Pre-Cambrian period and later shaped by large archways in the Late Cretaceous (Teixeira \& Cordani 2007). The Serra da Mantiqueira was part of a large crystalline plateau, and in the Triassic period this plateau underwent a process of bending and fracturing. After extensive erosive work and geological processes during the quaternary period, this plateau became massive, with isolated points and deep valleys (Meireles et al. 2014).

In regions of occurrence of nebular forests, there are areas with climatic and topographic conditions favorable to the regular formation of fogs. These areas present well-developed natural forests that, because they remain frequently enveloped in fog and clouds, are generally called cloud forests (Bruijnzeel et al. 2010). These forests account for only $2.5 \%$ of the total area of tropical forests in the world, with an overall surface area of approximately $380,000 \mathrm{~km}^{2}$ (Bubb et al. 2004). In Brazil, they are represented mainly by the montane and upper montane rainforests along the Serra do Mar in the states of Santa Catarina, Paraná, São Paulo, and Rio de Janeiro, in small stretches of the Serra da Mantiqueira de Minas Gerais, and still high in the plateaus and mountains of the Amazon, such as Pico da Neblina and Monte Roraima (Oliveira-Filho 2009; Bertoncello et al. 2009). These forests are responsible for hidden precipitation, that is, additional water entry into the ecosystem through the fog, by interception of water through the treetops and subsequent drainage to the forest floor (Arcova 2013). Thus, for these localities, the abstraction of water from the atmosphere constitutes an important process of the hydrological cycle of the hydrographic basins (Bruijnzeel et al. 2010, Arcova 2013).

The forests of Serra da Mantiqueira are still little known, and their floristic composition and richness have been described in some places by Oliveira-Filho \& Fontes (2000), França \& Stehmann (2004), Meireles et al. (2008), Valente et al. (2011), Salimena et al. (2013), Meireles et al. (2014), Santiago et. al. (2018), Oliveira-Filho et al. (2013), and Pompeu et al. (2014), among others. Nevertheless, the great environmental heterogeneity presented by this mountain chain has not been sufficiently detailed (Martinelli 2007). Among the least known forest formations are the cloud dwarf forests (sensu Oliveira-Filho et al. 2013).

The aspects that involve the cloud dwarf forests are related to the fact of their immersion in the cloud layer and to the local hydrological cycle (Oliveira-Filho \& Fontes 2000). They occur in narrow altitude belts, in ridges of mountainous relief, or in mountain peaks, with a distribution of species similar to archipelagos (Vazquez-Garcia 1995). The abundance, diversity, and distribution of cloud dwarf forest species are determined by global and regional climatic processes that operate on the phylogenetic lines observed over time on a geographic scale (Brown et al. 1996). The geographic distribution of the taxa is unique, being determined by their autoecological characteristics, geoclimatic barriers, climatic changes, and historical ecological processes (Brown et al. 1996). The discontinuous distribution of the altitude massifs of the Serra da Mantiqueira promotes 
the isolation of the cloud dwarf forests and the species that compose them, being able to restrict gene flow and to prevent the connectivity between the different populations. This process favors the occurrence of species and local endemism (Safford 1999). The species that occur in cloud dwarf forests tolerate adverse conditions such as freezing night temperatures, high temperatures during the day, frost, climatic seasonality, and physical changes such as high light intensity and low atmospheric pressure (Oliveira-Filho \& Fontes 2000), with the presence of haze (Bruijnzeel et al. 2010). In addition, it is important to note that the dwarf forests are more likely to be found in high-altitude areas.

Seeking to broaden the knowledge about the altitude formations of the Serra da Mantiqueira, this study was developed with the objective of determining the floristic composition of the cloud dwarf forests of Ibitipoca State Park (ISP) and the contribution of the tropical and temperate distribution elements in this phytophysiognomy.

\section{Material and Methods}

\section{Study area}

ISP is located in Minas Gerais, between the municipalities of Lima Duarte, Bias Fortes, and Santa Rita do Ibitipoca, at coordinates $21^{\circ} 40^{\prime}-21^{\circ} 44$ 'S and $43^{\circ} 52^{\prime}-43^{\circ} 55^{\prime}$ ' $\mathrm{W}$ and covers an area of 1,488 ha. The region's climate is classified as Cwb, according to Köppen (1948), with dry winters and rainy and mild summers. The Serra do Ibitipoca has relief formed by high escarpments or hills, with variable altitudes between $1100 \mathrm{~m}$ and $1784 \mathrm{~m}$ (Rodela \& Tarifa 2002) (Figure 1).

ISP is one of the many areas of rocky outcropping in Southeastern Brazil, where there are Proterozoic metastatic rocks of the Andrelândia Group, mainly quartzites and schists, which are on a basement formed of orthogneisses and migmatites belonging to the Mantiqueira Group (Nummer 1991, Corrêa Neto \& Baptista Filho 1997). Soils are acidic, alkaline, dystrophic, kaolinitic, and shallow, with little water retention capacity, and support a mosaic of complex vegetation (Dias et al. 2002).

The predominant landscape in ISP is represented by savannas and prairies, described in the literature as campos rupestres, and most of the forest cover is cloud dwarf forests that cover about 226 ha or $15.6 \%$ of the surface of the park (Oliveira- Filho et al. 2013). The distribution of most cloud dwarf forests in ISP appears to be closely related to the local drainage network, housed in depressions in the ground and in the bottom of valleys, where there is high deposition of sediment and water (Oliveira-Filho et al. 2013). The identification and recognition of the vegetative types of ISP in this work follow the proposal of OliveiraFilho et al. (2013) (Figure 2).

\section{Floristic composition}

In order to evaluate the floristic composition of the cloud dwarf forests of ISP, 12 field campaigns were carried out to collect botanical material, from September 2014 to September 2015, lasting three days each, in different areas of cloud dwarf forests distributed in varying altimetric heights, between 1100 and 1700 m.s.m. The collection was performed by traversing trails inside the dwarf forests, seeking to cover as much of the area as possible, following the method of walking (Filgueiras et al. 1994). The classification of the species habit followed Gonçalves \& Lorenzi (2007).
The collected material was herborized according to the techniques of Mori et al. (1989) and deposited in the collection of the CESJ Herbarium of the Federal University of Juiz de Fora (acronym according to Thiers 2016), where it was identified with the help of specialized literature and comparison with the collection of ISP already deposited in the collection, in addition to consulting specialists. The names of the angiosperm families followed the system proposed by APG IV (2016). The synonymy, the spelling and the authorship of the names of the species were conferred through Flora do Brasil 2020 (under construction). Materials deposited in the collections of the herbariums CESJ, BHCB, ESAL, and RB (acronyms according to Thiers 2016) from botanical works in ISP for more than 40 years were included in the floristic listing.

\section{Phytogeography}

For the phytogeography analyses, the genera were classified into seven phytogeographic groups delimited based on their current centers of diversity cited by Safford (2007). The groups are: Austral-Antarctic from temperate regions of the Southern hemisphere; Holistic - center of diversity in temperate Northern hemisphere; Generalized Tempering; Cosmopolitan - worldwide distribution; Tropical Species - at least 5\% of species on a second continent; Neotropical; and Endemic to Brazil. The geographic distribution of the species was based on the literature and on specialized sites, such as speciesLink (CRIA 2001), w3 Tropicos (MBG 2014), and BFG (2015).

\section{Results}

\section{Floristic composition}

A total of 372 species were recorded, distributed in 209 genera and 73 families of phanerogams, with only one species, Podocarpus sellowii Klotzsch (Podocarpaceae), representative of the group of gymnosperms. Of the total specimens, 337 were identified at a specific level, the remaining 28 at the gender level, and seven at the family level (Table 1).

The richest families are Orchidaceae (84 spp.), Asteraceae (39 spp.), Melastomataceae (21 spp.), Bromeliaceae (20 spp.), Myrtaceae (18 spp.), and Rubiaceae (17spp) (Figure 3).

The genera with the greatest richness were Epidendrum (nine spp.), Leandra (nine spp.), Pleurothallis (nine spp.), Mikania (seven spp.), Miconia (seven spp.), Tillandsia (six spp.), Solanum (six spp.), and Myrcia (six spp.) (Figure 4).

Among the 372 species found, 103 are arboreal (27.7\%), 83 shrub (22.3\%), 82 epiphytic herbs (22\%), 80 terrestrial herbs (21.5\%), and 23 lianas (6.5\%). Among the tree species, the families Myrtaceae with 17 species and Melastomataceae with 14, with greater richness, stand out. Among the shrubs, the greatest wealth is of the family Asteraceae with 21 spp., followed by Rubiaceae (eight) and Melastomataceae (seven). The terrestrial herbaceous habit was highlighted among the Orchidaceae families with 23 species, Asteraceae with nine, and Bromeliaceae with eight. Epiphytic species predominated in the Orchidaceae family, with 61 species. Among the lianas, the most representative family was Asteraceae with six species, followed by Apocynaceae and Smilacaceae with four each. 
Moreira, B. et al.
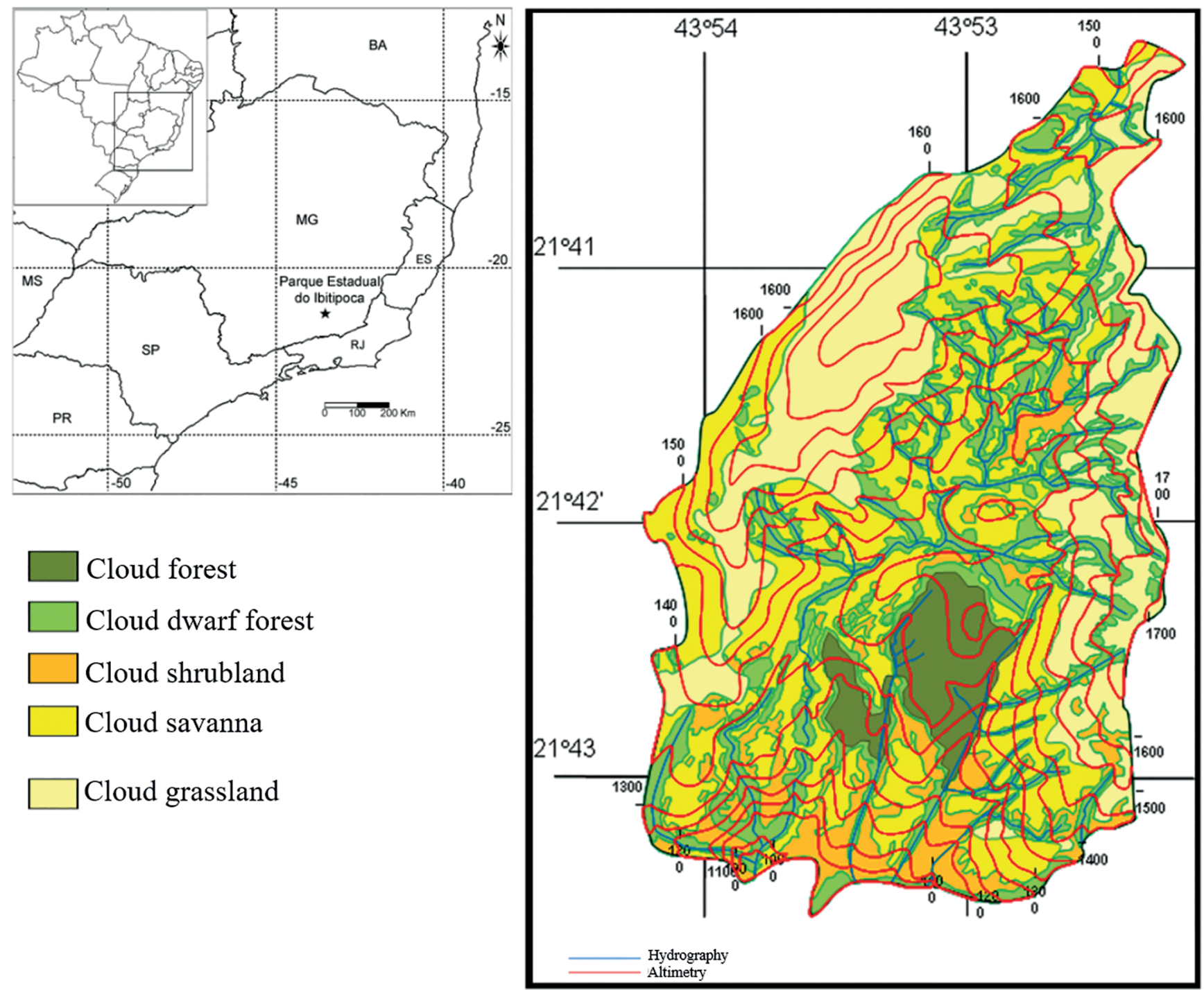

Figure 1. Geographic location of Ibitipoca State Park, Serra da Mantiqueira, Southeastern Brazil, with emphasis on its phytophysiognomies (adapted from Oliveira-Filho et al. 2013).

Among the species found in the cloud dwarf forests of ISP, seven have some degree of extinction threat: Octomeria wawrae, Ocotea odorifera, and Vriesea penduliflora classified as "endangered"; Hindsia ibitipocensis as "critically endangered" (CR); and Baccharis lychnophora, Schlumbergera opuntioides, and Sinningia tuberosa as "vulnerable" (VU) (Martinelli \& Morais 2013).

\section{Phytogeography}

The genera with a tropical diversity center represent $86.5 \%$ of the total, distributed among 126 neotropical (60\%), 45 large tropical $(21.5 \%)$, and 10 endemic genera of Brazil (5\%). The genus with a diversity center in temperate regions corresponded to $13.5 \%$ of the total, distributed among seven genera austral-antarctic $(3.5 \%)$, one of holarian origin $(0.5 \%)$, two of large temperate origin $(1 \%)$, and 17 (8.5\%) cosmopolitan (Table 2).

\section{Discussion}

\section{Floristic composition}

In the cloud dwarf forests of ISP is the presence of a dense understory, where the arboreal individuals branch to a low height. The floristic profile presents typical characteristics of forest formations of altitude. However, it also presents characteristic species of fields and savannas (Oliveira-Filho et al. 2013). The cloud dwarf forests of ISP present a canopy of about 10 meters, with few emergent trees such as Eugenia brasiliensis, Cupania zanthoxyloides, and Solanum mauritanium. Just below the sub-forest, at about five meters, we can find species such as Agarista pulchella, Leandra melastomoides, Leandra aurea, Myrcia splendens, and the palm tree Geonoma schottiana, which has a large fruit production that serves as food for the local fauna (Oliveira-Filho et al. 2013). Soils, derived from quartzite, are generally shallow and poor in minerals, but the feedback from litter decomposition can sustain medium-sized vegetation (Oliveira-Filho et al. 2013). 

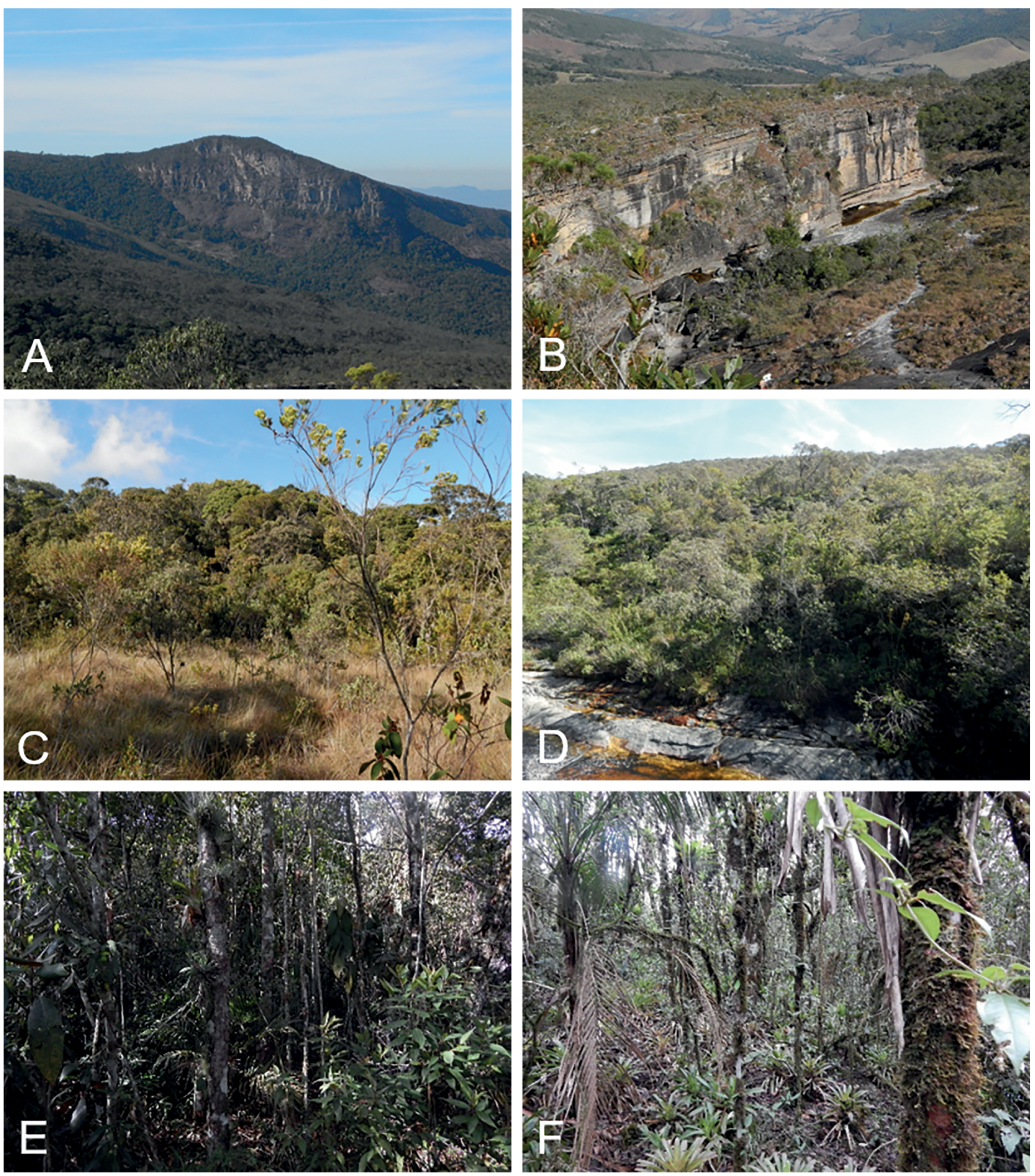

Figure 2. A-B. Phytophysiognomies of Ibitipoca State Park; C-D. Details of cloud dwarf forests border, highlighting the transition environments; E-F. Details of inside cloud dwarf forests, Ibitipoca State Park, Minas Gerais, Brazil. 
Moreira, B. et al.

Table 1. Composition of the phanerogamic flora of the cloud dwarf forests of Ibitipoca State Park, Serra da Mantiqueira, Southeastern Brazil. The species are listed by family and in alphabetical order, accompanied by the habit ( $\mathrm{Tr}$ - tree, Sh - shrub, Li - liana, Th - terrestrial herb, Eh - epiphytic herb) and the testimonial material that is deposited in the herbariums CESJ, BHCB , ESAL, and RB.

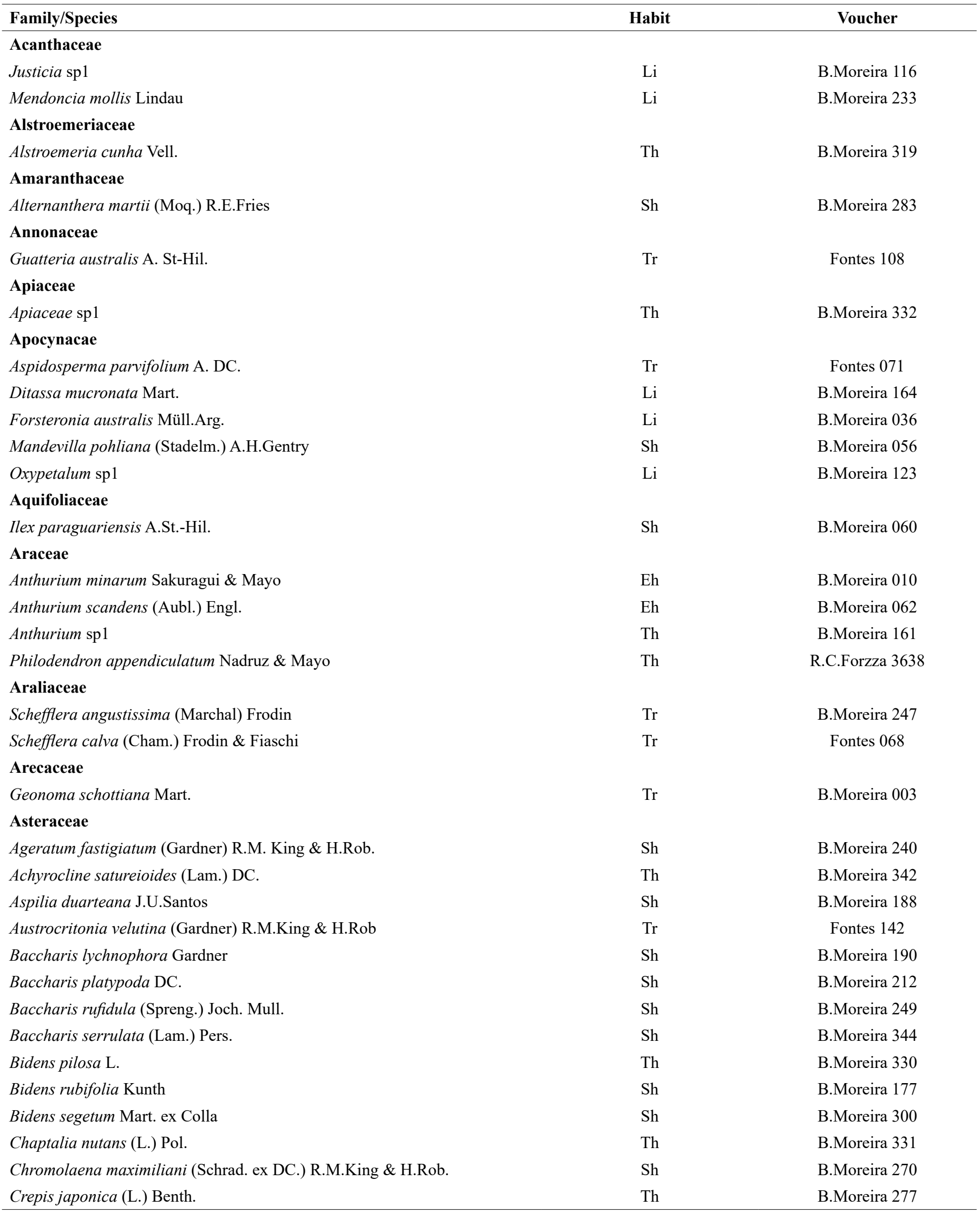


Continued Table 1.

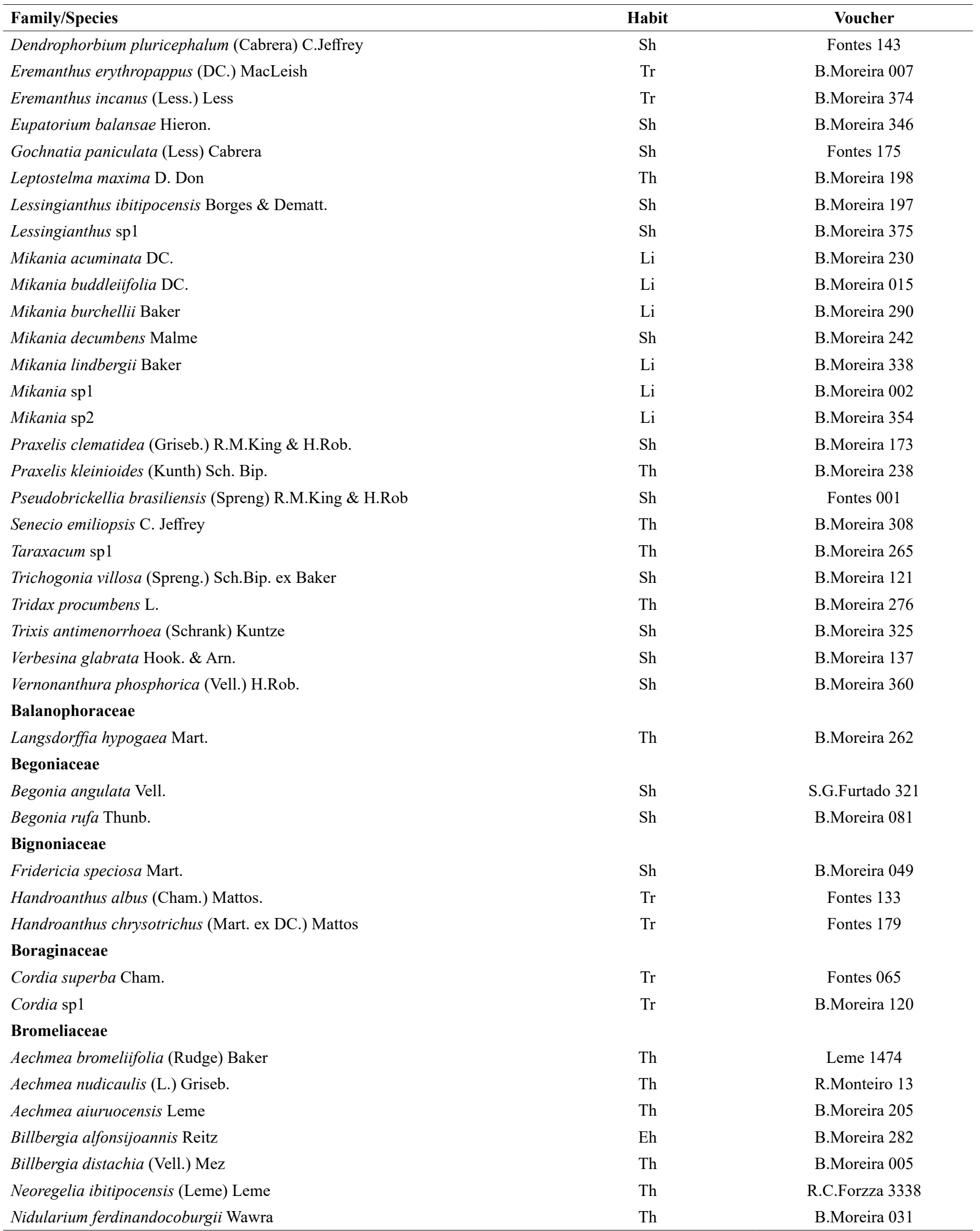


Moreira, B. et al.

Continued Table 1.

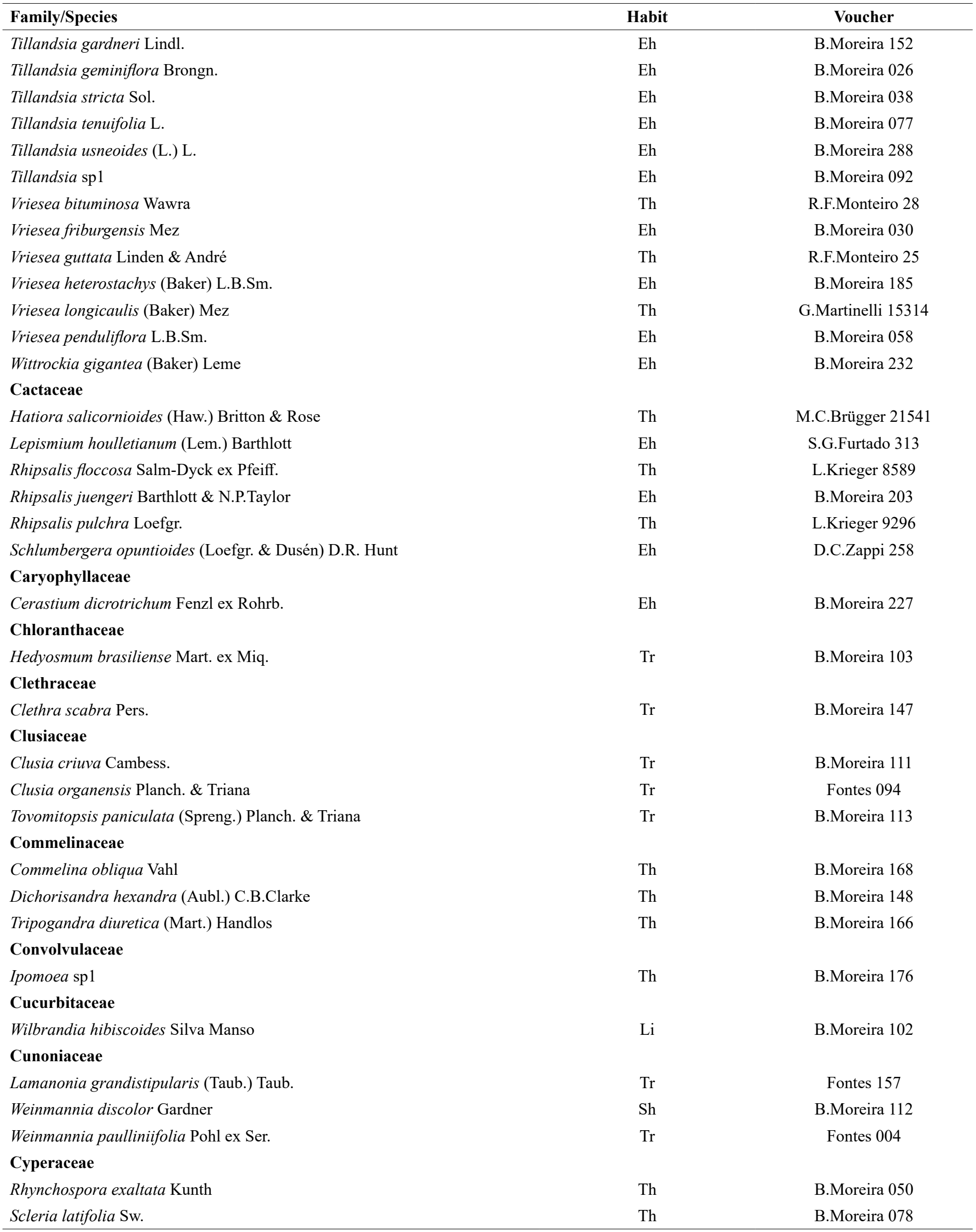


Continued Table 1.

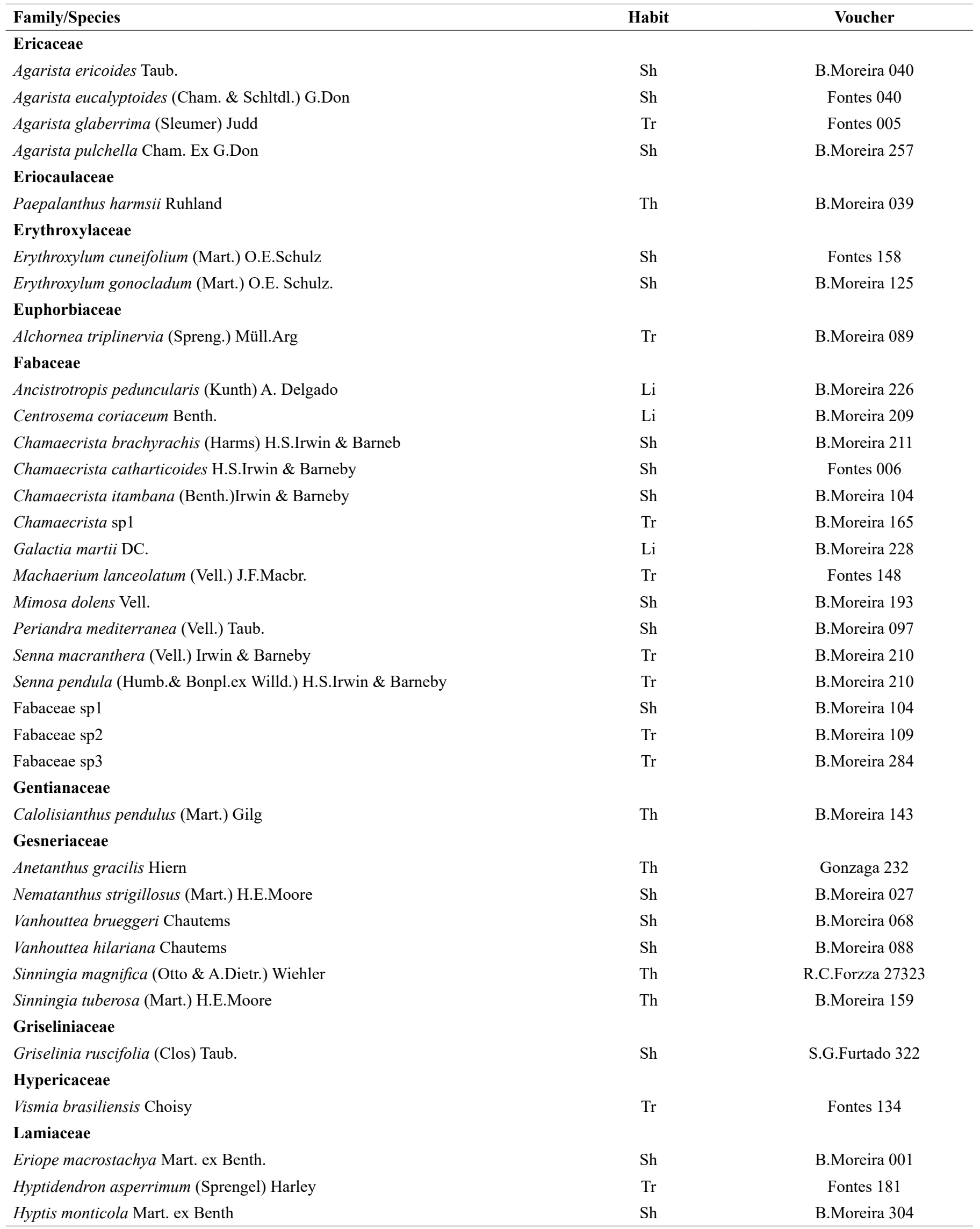


Moreira, B. et al.

Continued Table 1.

\begin{tabular}{|c|c|c|}
\hline Family/Species & Habit & Voucher \\
\hline Mesosphaerum suaveolens (L.) Kuntze & Th & B.Moreira 218 \\
\hline Vitex sellowiana Cham. & $\operatorname{Tr}$ & B.Moreira 091 \\
\hline Ocotea odorifera (Vell.) Rohwer & $\operatorname{Tr}$ & B.Moreira 260 \\
\hline Ocotea pulchella (Nez \& Mart.) Mez & $\operatorname{Tr}$ & B.Moreira 236 \\
\hline Ocotea $\mathrm{sp} 3$ & $\operatorname{Tr}$ & B.Moreira 126 \\
\hline Nectandra lanceolata Nees & $\operatorname{Tr}$ & B.Moreira 252 \\
\hline \multicolumn{3}{|l|}{ Loasaceae } \\
\hline Aosa sp1 & Th & B.Moreira 271 \\
\hline \multicolumn{3}{|l|}{ Lythraceae } \\
\hline Cuphea thymoides Cham \& Schltdl. & Sh & B.Moreira 237 \\
\hline \multicolumn{3}{|l|}{ Malpighiaceae } \\
\hline Byrsonima cuneifolia Griseb. & $\mathrm{Sh}$ & B.Moreira 292 \\
\hline Byrsonima variabilis A.Juss. & $\mathrm{Sh}$ & B.Moreira 028 \\
\hline Heteropterys pteropetala A. Juss. & $\mathrm{Sh}$ & B.Moreira 094 \\
\hline Mascagnia sepium (A.Juss.) Griseb. & $\mathrm{Li}$ & B.Moreira 048 \\
\hline \multicolumn{3}{|l|}{ Malvaceae } \\
\hline Callianthe montana (A. St.-Hil.) Donell \& C. Takeuch & $\mathrm{Sh}$ & B.Moreira 253 \\
\hline Triumfetta $\mathrm{sp} 2$ & Sh & B.Moreira 269 \\
\hline \multicolumn{3}{|l|}{ Melastomataceae } \\
\hline Leandra aurea (Cham.) Cogn. & $\operatorname{Tr}$ & B.Moreira 141 \\
\hline Leandra carassana (DC.) Cogn. & $\operatorname{Tr}$ & B.Moreira 082 \\
\hline Leandra foveolata (DC.) Cogn. & $\mathrm{Sh}$ & B.Moreira 054 \\
\hline Leandra fragilis Cogn & $\operatorname{Tr}$ & B.Moreira 315 \\
\hline Leandra gardneriana Cogn. & $\mathrm{Sh}$ & B.Moreira 131 \\
\hline Leandra melastomoides Raddi & $\operatorname{Tr}$ & B.Moreira 118 \\
\hline Leandra pennipilis (Triana) Cogn. & $\operatorname{Tr}$ & B. Moreira 75 \\
\hline Leandra riedeliana (O.Berg ex Triana) Cogn. & $\mathrm{Sh}$ & B.Moreira 258 \\
\hline Leandra vesiculosa Cogn. & $\operatorname{Tr}$ & B.Moreira 201 \\
\hline Miconia chartacea Triana & $\operatorname{Tr}$ & B.Moreira 084 \\
\hline Miconia cinnamomifolia (DC.) Naudin & $\operatorname{Tr}$ & Fontes 150 \\
\hline Miconia corallina Spring & $\operatorname{Tr}$ & B.Moreira 074 \\
\hline Miconia latecrenata (DC.) Naudin & $\operatorname{Tr}$ & B.Moreira 013 \\
\hline Miconia pusilliflora (DC.) Naudin & $\operatorname{Tr}$ & B.Moreira 225 \\
\hline Miconia sellowiana Naudin & $\operatorname{Tr}$ & B.Moreira 053 \\
\hline
\end{tabular}


Continued Table 1.

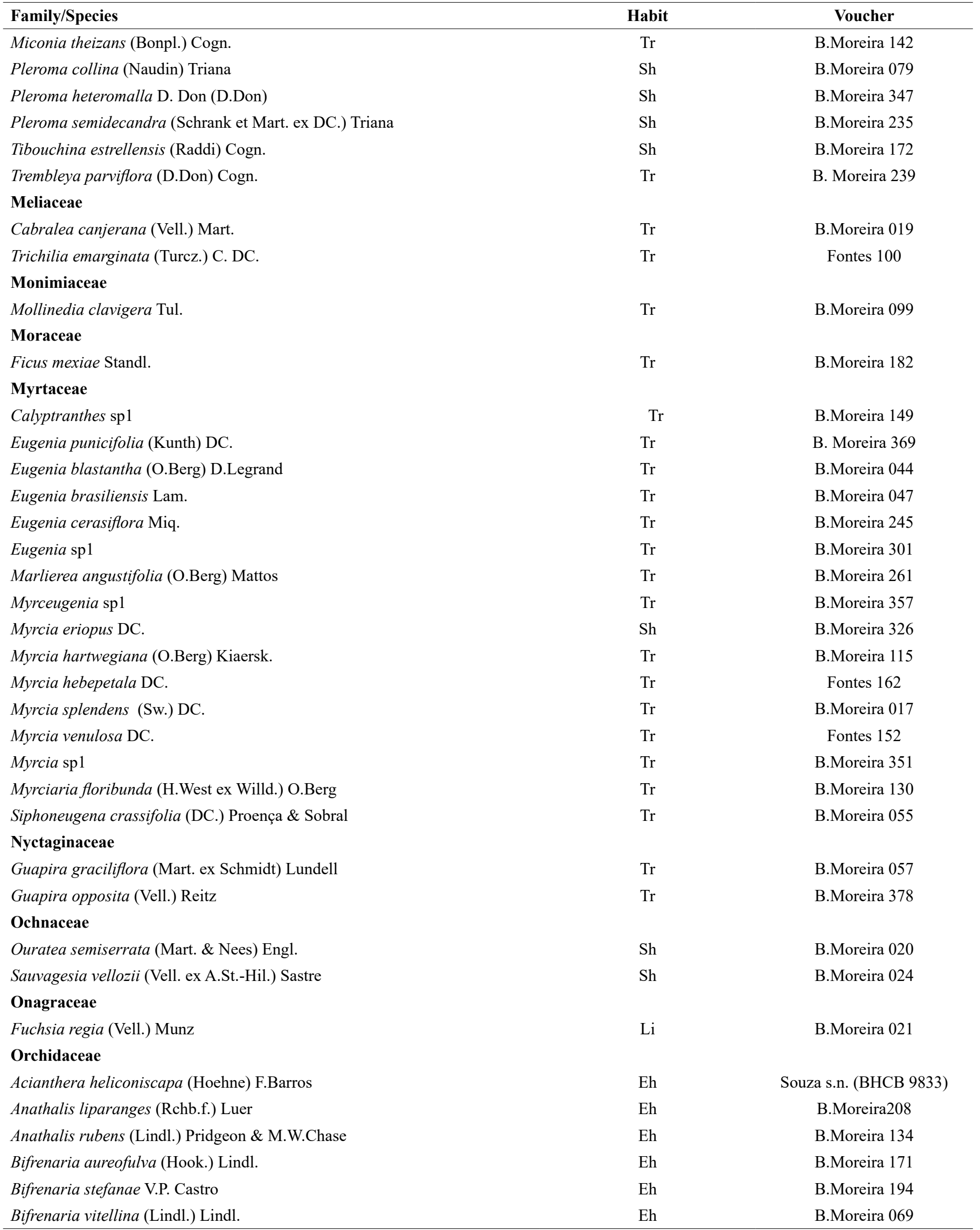


Moreira, B. et al.

Continued Table 1.

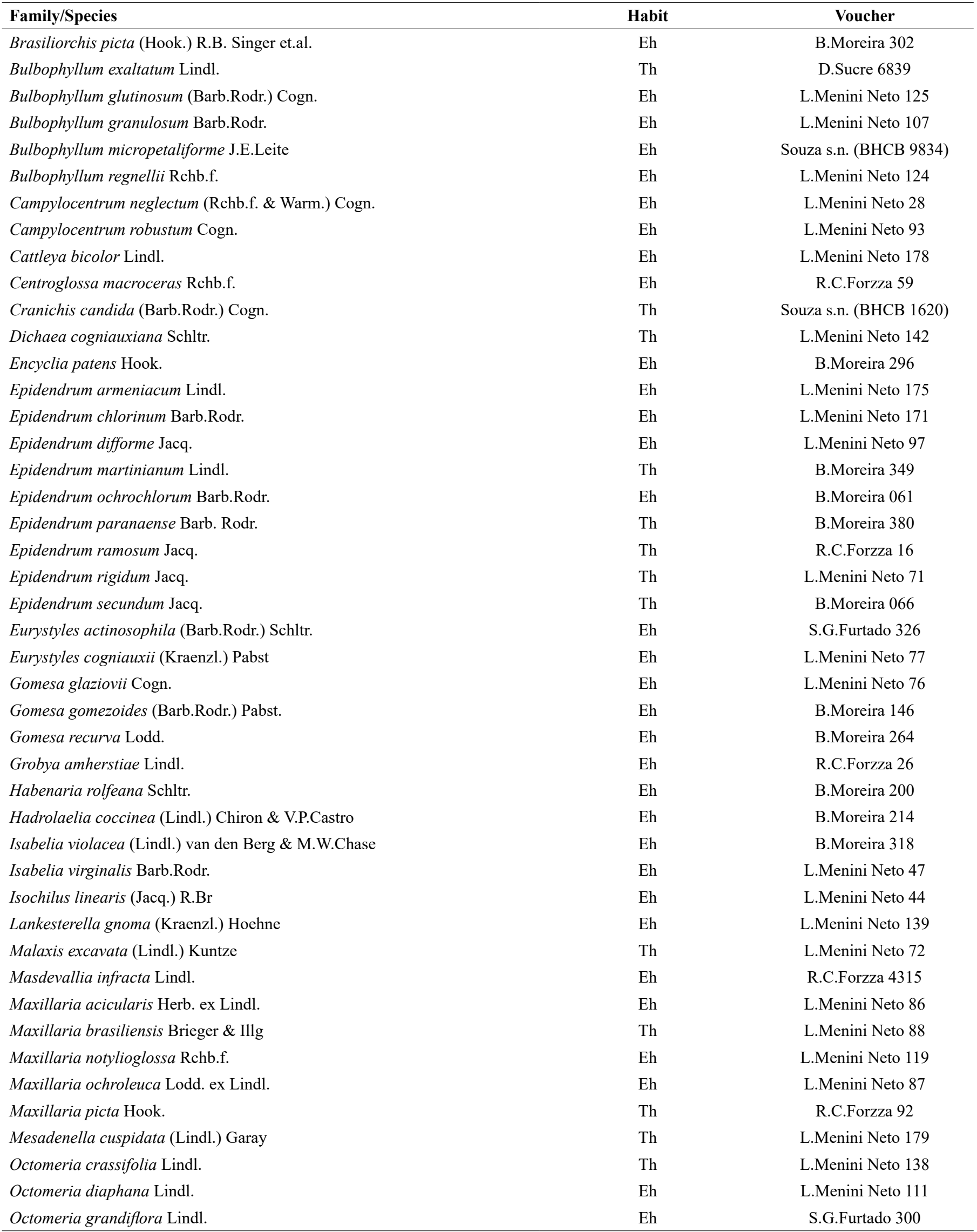


Continued Table 1.

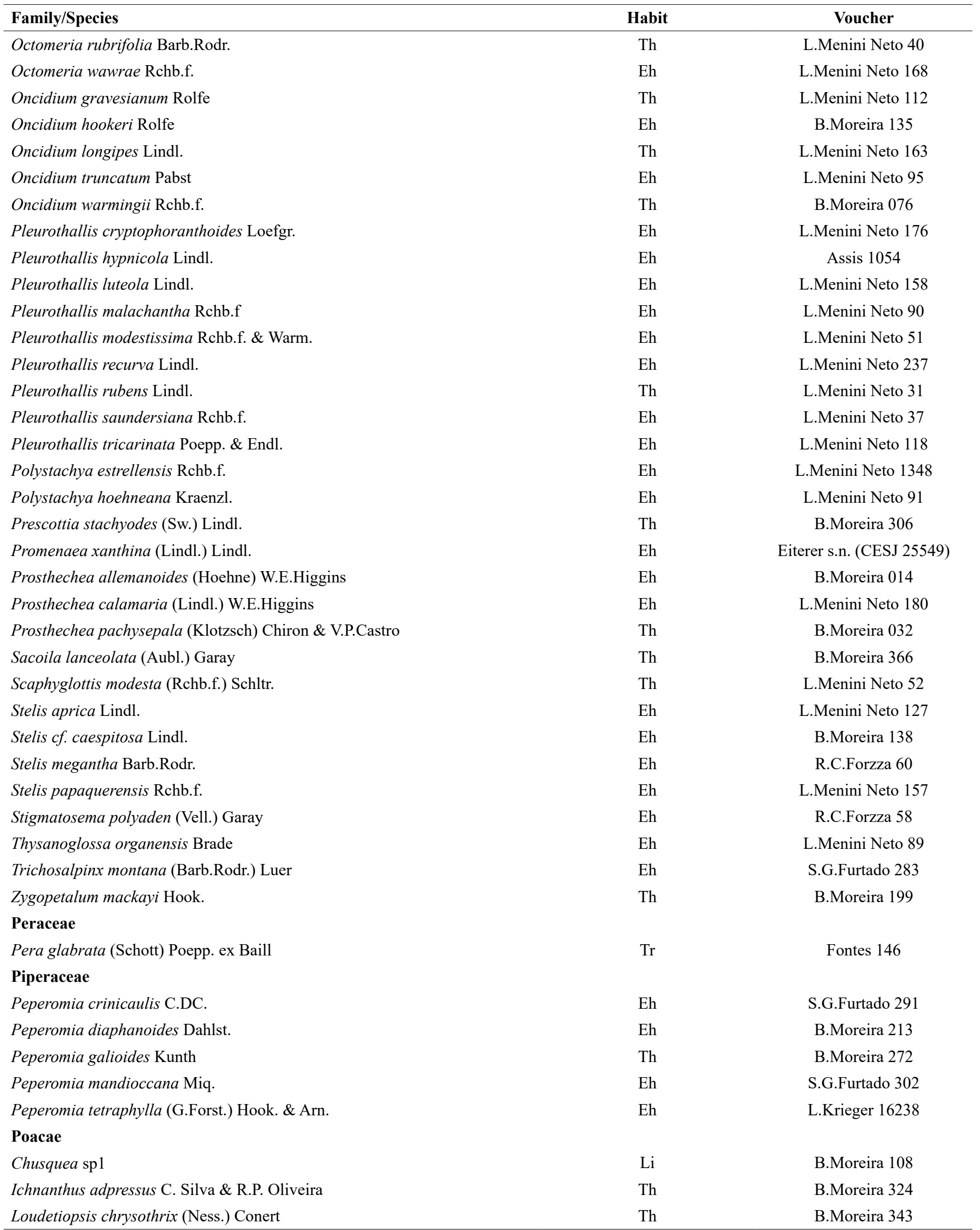


Moreira, B. et al.

Continued Table 1.

\begin{tabular}{|c|c|c|}
\hline Family/Species & Habit & Voucher \\
\hline Oplismenus hirtellus (L.) P. Beauv. & $\mathrm{Th}$ & B.Moreira 221 \\
\hline Setaria $\mathrm{sp} 1$ & $\mathrm{Th}$ & B.Moreira 154 \\
\hline Podocarpus sellowii Klotzsch & $\operatorname{Tr}$ & Fontes 064 \\
\hline \multicolumn{3}{|l|}{ Polygalaceae } \\
\hline \multicolumn{3}{|l|}{ Primulaceae } \\
\hline Myrsine coriacea (Sw.) R. Br. ex Roem. \& Schult. & $\operatorname{Tr}$ & B.Moreira 035 \\
\hline Myrsine ferruginea (Ruiz \& Pav.) Spreng. & $\operatorname{Tr}$ & B.Moreira 187 \\
\hline Myrsine lancifolia Mart. & $\operatorname{Tr}$ & Fontes 151 \\
\hline Roupala montana Aubl. & $\operatorname{Tr}$ & B.Moreira 305 \\
\hline Roupala rhombifolia Mart. & $\operatorname{Tr}$ & Fontes 164 \\
\hline \multicolumn{3}{|l|}{ Rhamnaceae } \\
\hline Rhamnus sphaerosperma $\mathrm{Sw}$. & $\operatorname{Tr}$ & B.Moreira 096 \\
\hline \multicolumn{3}{|l|}{ Rubiaceae } \\
\hline Amaioua intermedia Mart. ex Schult. \& Schult.f. & $\mathrm{Sh}$ & B.Moreira 191 \\
\hline Borreria capitata (Ruiz \& Pav.) DC. & Th & B.Moreira 224 \\
\hline Borreria sp1 & Th & B.Moreira 313 \\
\hline Coccocypselum condalia (Ruiz \& Pav.) Pers. & $\mathrm{Th}$ & B.Moreira 022 \\
\hline Hindsia ibitipocensis Di Maio & $\mathrm{Sh}$ & B.Moreira 064 \\
\hline Palicourea marcgravii A.St.-Hil. & $\mathrm{Sh}$ & B.Moreira 119 \\
\hline Posoqueria acutifolia Mart. & $\operatorname{Tr}$ & B.Moreira 178 \\
\hline Psychotria leiocarpa Cham. \& Schltdl. & $\mathrm{Sh}$ & B.Moreira 273 \\
\hline Psychotria ruelliifolia (Cham. \& Schltdl.) Müll.Arg. & $\mathrm{Sh}$ & B.Moreira 316 \\
\hline Psychotria stachyoides Benth. & Sh & B.Moreira 029 \\
\hline Psychotria vellosiana Benth. & $\operatorname{Tr}$ & B.Moreira 025 \\
\hline Rudgea sessilis (Vell.) Müll.Arg. & $\operatorname{Tr}$ & Fontes 055 \\
\hline \multicolumn{3}{|l|}{ Rutaceae } \\
\hline Dictyoloma vandellianum A. Juss. & $\operatorname{Tr}$ & Fontes 024 \\
\hline Esenbeckia grandiflora Mart. & $\mathrm{Sh}$ & B.Moreira 297 \\
\hline Zanthoxylum rhoifolium Lam. & $\operatorname{Tr}$ & Fontes 154 \\
\hline \multicolumn{3}{|l|}{ Sabiaceae } \\
\hline Meliosma sellowii Urb. & $\operatorname{Tr}$ & Fontes 166 \\
\hline \multicolumn{3}{|l|}{ Santalaceae } \\
\hline Phoradendron sp1 & Th & B.Moreira 128 \\
\hline Phoradendron $\mathrm{sp} 2$ & Th & B.Moreira 353 \\
\hline
\end{tabular}


Continued Table 1.

\begin{tabular}{|c|c|c|}
\hline Family/Species & Habit & Voucher \\
\hline \multicolumn{3}{|l|}{ Sapindaceae } \\
\hline Cupania vernalis Cambess. & $\operatorname{Tr}$ & B.Moreira 018 \\
\hline Matayba cristae Reitz & $\operatorname{Tr}$ & Fontes 167 \\
\hline Matayba guianensis (Aubl.) Radlk. & $\operatorname{Tr}$ & B.Moreira 008 \\
\hline \multicolumn{3}{|l|}{ Smilacaceae } \\
\hline Smilax elastica Griseb. & $\mathrm{Li}$ & B.Moreira 217 \\
\hline Smilax staminea Griseb. & $\mathrm{Li}$ & B.Moreira 379 \\
\hline Smilax stenophylla A.DC. & $\mathrm{Li}$ & B.Moreira 359 \\
\hline Brunfelsia brasiliensis (Spreng.) L.B.Sm. \& Downs & $\mathrm{Sh}$ & B.Moreira 110 \\
\hline Dyssochroma viridiflorum (Sims) Miers & Sh & B.Moreira 274 \\
\hline Solanum americanum Mill. & Th & B.Moreira 250 \\
\hline Solanum didymum Dunal & $\mathrm{Sh}$ & B.Moreira 254 \\
\hline Solanum kriegeri Giacomin \& Stehmann & Th & B.Moreira 063 \\
\hline Solanum mauritianum Scop. & $\operatorname{Tr}$ & B.Moreira 278 \\
\hline Solanum swartzianum Roem. \& Schult. & $\operatorname{Tr}$ & B.Moreira 180 \\
\hline Solanum sp1 & Sh & B.Moreira 090 \\
\hline Solanaceae sp1 & Sh & B.Moreira 085 \\
\hline \multicolumn{3}{|l|}{ Urticaceae } \\
\hline Cecropia glaziovii Snethl. & $\operatorname{Tr}$ & B.Moreira 311 \\
\hline \multicolumn{3}{|l|}{ Verbenaceae } \\
\hline Lantana fucata Lindl. & Sh & B.Moreira 169 \\
\hline Verbena litoralis Kunth & Th & B.Moreira 080 \\
\hline \multicolumn{3}{|l|}{ Violaceae } \\
\hline Anchietea pyrifolia (Mart.) G.Don & $\mathrm{Li}$ & B.Moreira 073 \\
\hline \multicolumn{3}{|l|}{ Vochysiaceae } \\
\hline Qualea cordata (Mart.) Spreng. & $\operatorname{Tr}$ & B.Moreira 095 \\
\hline Vochysia tucanorum Mart. & $\operatorname{Tr}$ & B.Moreira 133 \\
\hline \multicolumn{3}{|l|}{ Winteraceae } \\
\hline Drimys brasiliensis Miers & $\operatorname{Tr}$ & B.Moreira 329 \\
\hline
\end{tabular}




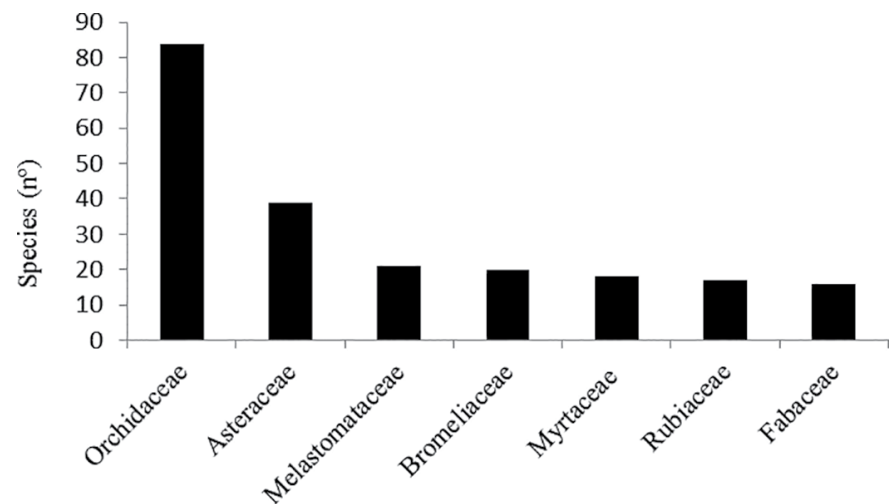

Figure 3. Most representative families in the cloud dwarf forests of the State Park of Ibitipoca, Serra da Mantiqueira, Brazil.

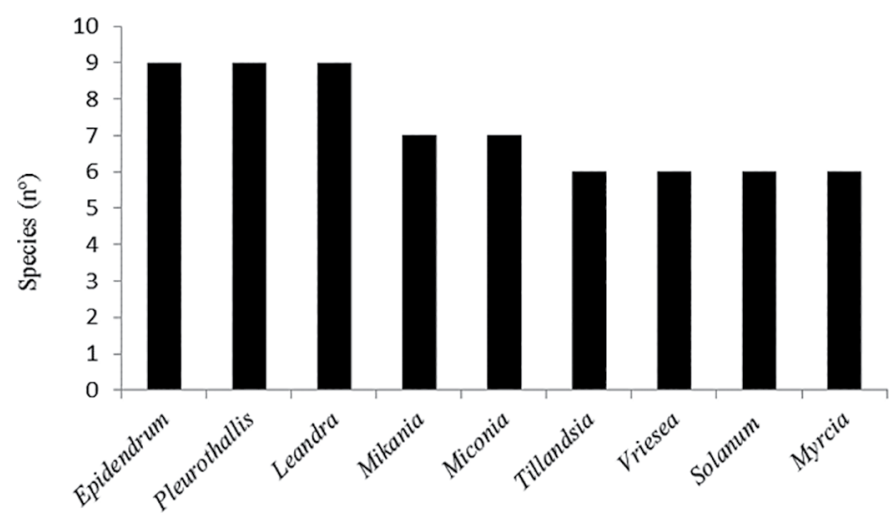

Figure 4. Most representative genera in the cloud dwarf forests of the State Park of Ibitipoca, Serra da Mantiqueira, Brazil.

The tree species are represented mainly by the families Melastomataceae and Myrtaceae. This floristic pattern meets the standards obtained by Oliveira-Filho \& Fontes (2000), Santiago et al. (2018), and Eisenlohr \& Oliveira-Filho (2015), who found Myrtaceae and Melastomataceae as the richest families in tree species for the Atlantic Forest in other regions of high altitude. These families also are found with high species richness in the survey carried out by Pereira et al. (2006) in remnants of vegetation in the Serra do Itatiaia. The families Myrtaceae and Melastomataceae are also considered Neotropical cloud forest characteristics by Webster (1995) and Scheer \& Mocochinski (2009).

In the cloud dwarf forests of ISP, indicative genera of highland forests in the Neotropical Region and in Brazil include Clethra, Drimys, Roupala, Weinmannia, Podocarpus, and Myrceugenia (França \& Stehmann 2004, Meireles et al. 2008). The cloud dwarf forests have a floristic composition distinct from the seasonal forests located in lower altitudes, being common to observe endemic species and several of them belonging to genera frequently observed in cloud forests all over the globe, being highlighted genera of high wealth in Andean mountain formations (Hamilton et al. 1995), such as Clethra and Rhamnus, genera shared between the ISP dwarf forests and the Andean tropical montane forests. Our results are closely related to Bertoncello et al. (2011) phytogeographic analysis, that find Drimys brasiliensis, Rhamnus sphaerosperma and Weinmannia paulliniifolia as preferential or indicator tree species in the cloud forests group compared to other forest subtypes in south and southeast Brazil.
The Asteraceae, Rubiaceae, and Melastomataceae families were noted for their richness in the shrub strata of the cloud dwarf forests. The high Asteraceae richness probably is associated to its diversity of habits, with species occupying different strata of the vegetation. In cloud forests located in regions of altitude in the South Region of Brazil, Asteraceae also presents high representativeness, although in Brazil, it presents greater richness in regions of rupestrian fields (Falkenberg 2003, Borges et al. 2010). Melastomataceae and Rubiaceae were also highlighted in studies in the Serra da Mantiqueira and Serra Negra (MG), due to the high richness of the shrub taxa (Salimena et al. 2013, Meireles et al. 2014). The genera Baccharis, Psychotria, Leandra, and Pleroma (three species each) were the most representative among the shrubs. These data are in agreement with Mocochinski \& Scheer (2008) and Meireles et al. (2014), who found Leandra and Pleroma as shrub genera with high richness and a representative number of endemic species in high montane formations.

Terrestrial herbs are the main components of the ISP cloud dwarf forests' sub-forest, especially in humid and shady places, and are mainly represented by species of the Asteraceae and Orchidaceae families, understory plants of the genera Coccocypselum and Anthurium, as well as species of the family Commelinaceae, such as Dichorisandra hexandra and Commelina obliqua. The herbaceous earth species contribute to the floristic increase of forest areas and to the composition of the soil, because they have a shorter life cycle than species of arboreal habit (Martins-Ramos et al. 2011). In the present study, the terrestrial herbs correspond to about $21.5 \%$ of the total species, a value close to that obtained for the shrub species (22.3\%). Pereira-Silva et al. (2007), Meireles et al. (2014), and Santiago et al. (2018), in studies carried out in different regions of the Serra da Mantiqueira, recorded Asteraceae as the family with the highest species richness. The high richness of this family in the terrestrial herbaceous stratum can be related to the direct contact of the cloud dwarf forests with the adjacent altitude fields, which facilitates the establishment of Asteraceae species in these areas (Pillar et al. 2009). The family is one of the most diverse in global terms and can be found in all types of habitats around the world (Judd et al. 2009).

Among the lianas, the Chusquea and Mikania genera are well distributed throughout the study area. Bamboos of the genus Chusquea are frequent in the cloud dwarf forests of ISP and generally form clusters near the areas of greater humidity, bordering the rivers and streams. Chusquea and Mikania occur preferentially in Atlantic South Atlantic formations (Safford 2007, Meireles et al. 2014).

The cloud dwarf forests have a high epiphytic rate, especially the families Orchidaceae and Bromeliaceae, which occupy diverse forest strata and collaborate for the high index of epiphytic species in a forest formation, besides the abundant presence of lichens that occupy the trunks of the trees, shrubs, and soil (Furtado 2016). In the present study, a high rate of epiphytic species was observed $(22 \%$ of the species sampled). These species can often be considered typical of cloud forests and may correspond to about $25 \%$ of the species sampled (Benzing 1998). Furtado (2016) has compiled a list of vascular epiphytes occurring in the cloud forests of ISP, composed of 222 species distributed in 81 genera and 22 families, of which Orchidaceae is the richest ( $85 \mathrm{spp}$.), corresponding to $28 \%$ of the vascular flora formation. Both the absolute number of species and the epiphytic quotient observed by Furtado (2016) correspond to one of the greatest diversities already sampled in studies of this nature in the Brazilian Atlantic Forest. 
Cloud Dwarf Forests of Ibitipoca State Park

Table 2. Phytogeographic groups of the genera represented in cloud dwarf forests of Ibitipoca State Park, Serra da Mantiqueira, Southeastern Brazil.

\begin{tabular}{|c|c|}
\hline Phytogeographic groups & Genera $\left(n^{0}\right)$ \\
\hline \multicolumn{2}{|l|}{ Temperate } \\
\hline Austral-antartic: Drimys, Fuchsia, Griselinia, Myrceugenia, Podocarpus, Polygala, Weinmannia & 7 \\
\hline Large temperate: Senecio, Dendrophorbium & 2 \\
\hline $\begin{array}{l}\text { Cosmopolitan: Bidens, Borreria, Brickellia, Caamembeca Cerastium, Commelina, Crepis, Ficus, Galactia, Ilex, Ipomoea, } \\
\text { Malaxis, Oplismenus, Rhynchospora, Solanum, Setaria, Taraxacum, Verbesina }\end{array}$ & 18 \\
\hline $\begin{array}{l}\text { Endemic of Brazil: Eremanthus, Grobya, Nematanthus, Trembleya, Aosa, Dyssochroma, Gomesa, Periandra, Vanhouttea, } \\
\text { Wittrockia. }\end{array}$ & 10 \\
\hline $\begin{array}{l}\text { Neotropical: Acianthera, Aechmea, Alchornea, Alstroemeria, Amaioua, Anathallis, Ancistrotropis, Anchietea, } \\
\text { Anetanthus, Anthurium, Aspidosperma, Aureliana, Austrocritonia, Baccharis, Bifrenaria, Billbergia, Brasiliorchis, } \\
\text { Brunfelsia, Byrsonima, Cabralea, Calolisianthus, Calyptranthes, Campylocentrum, Cattleya, Cecropia, Centroglossa, } \\
\text { Centrosema, Chaptalia, Chromolaena, Chusquea, Coccocypselum, Clusia, Cordiera, Cranichis, Cupania, Cuphea, } \\
\text { Dichaea, Dichorisandra, Dictyoloma, Ditassa, Emmeorhiza, Encyclia, Epidendrum, Eriope, Eupatorium, Eurystyles, } \\
\text { Forsteronia, Fridericia, Geonoma, Gomidesia, Guapira, Guatteria, Hadrolaelia, Handroanthus, Hatiora, Hedyosmum, } \\
\text { Heteropterys, Hillia, Hindsia, Hyptidendron, Ichnanthus, Isabelia, Isochilus, Lamanonia, Langsdorffia, Lankesterella, } \\
\text { Laplacea, Leandra, Leptostelma, Lessingianthus, Loudetiopsis, Machaerium, Mandevilla, Marlierea, Mascagnia, Matayba, } \\
\text { Masdevallia, Maxillaria, Mesadenella, Mesosphaerum, Miconia, Mollinedia, Myrcia, Myrciaria, Nectandra, Neoregelia, } \\
\text { Nidularium, Octomeria, Oncidium, Oxypetalum, Palicourea, Pera, Phoradendron, Piper, Philodendron, Pleroma, } \\
\text { Pleurothallis, Posoqueria, Praxelis, Prescottia, Promenaea, Prosthechea, Qualea, Roupala, Scaphyglottis, Schlumbergera, } \\
\text { Siphoneugena, Sinningia, Stelis, Stigmatosema, Struthanthus, Thysanoglossa, Tibouchina, Tillandsia, Tovomitopsis, } \\
\text { Trichogonia, Trichosalpinx, Tridax, Trixis, Verbena, Vernonanthura, Vismia, Vochysia, Vriesea, Wilbrandia, Zygopetalum. }\end{array}$ & 126 \\
\hline $\begin{array}{l}\text { Large tropical: Abutilon, Achyrocline, Agarista, Ageratum, Alternanthera, Andropogon, Aspilia, Begonia, Bulbophyllum, } \\
\text { Chamaecrista, Clethra, Cordia, Erythroxylum, Eugenia, Gochnatia, Habenaria, Hyptis, Justicia, Lantana, Meliosma, } \\
\text { Mendoncia, Mikania, Mimosa, Myrsine, Ocotea, Ouratea, Paepalanthus, Pavonia, Peperomia, Polystachya, Psychotria, } \\
\text { Rhipsalis, Rudgea Sacoila, Sauvagesia, Schefflera, Scleria, Senna, Smilax, Symplocos, Trichilia, Tripogandra, Triumfetta, } \\
\text { Vitex, Zanthoxylum. }\end{array}$ & 45 \\
\hline
\end{tabular}

In view of the above, it is possible to assume that the epiphytes play an important role in the cycles of the cloud dwarf forests. They also act in the local water cycle, since they interfere in the capture, storage, and slow release of water (Richardson et al. 2000). It is estimated that in some areas epiphytes can store about 3,000 liters/ha and provide water, nesting, and feeding materials for a wide range of animal species, from invertebrates to primates (Richardson et al. 2000). These factors alone justify the importance of the presence of epiphytes for the ecosystem as a whole.

The floristic profile of the ISP cloud dwarf forests presents floristic similarities at the family and genera levels with the Andes highland forests, also presenting characteristics that allow them to be associated with a transition environment between the rupestrian and highland Southeast Region of Brazil. Based on the predominance of the families Orchidaceae, Asteraceae, Bromeliaceae, Myrtaceae, Melastomataceae, and Rubiaceae, it can be affirmed that the cloud dwarf forests of ISP present very similar flora to the cloud dwarf forests of Serra Fina, Serra Negra (MG), and Agulhas Negras (RJ) (Oliveira-Filho \& Fontes 2000, Olíveira-Filho et al. 2005, Pereira et al. 2006, Bertoncello et al. 2011, Valente et al. 2011, Meireles et al. 2014).

Fontes (1997), in a study in the PEIB cloud forest, which he called "Mata Alta" (cloud forest), found Lauraceae as the richest family, followed by Myrtaceae and Rubiaceae. The author points out that this area differs substantially from the areas of cloud dwarf forests, which he called "Mata Baixa" (cloud dwarf forest), mainly in relation to the forest structure. Fontes (1997) recorded 127 species in the "Mata Alta", 63 in the "Mata Baixa" and only eight species common to the two habitats, indicating that they are two forest physiognomy very distinct. Menino (2013), in a study performed in the same sample area as Fontes (1997), found Psychotria suterella, Aspidosperma australe and Psychotria vellosiana as the species of high VI. Among these, only Psychotria vellosiana was sampled in the cloud dwarf forests, reinforcing the heterogeneity among the forest physiognomies. PEIB cloud forests are characterized by canopy rich in clearings, with a height of around 17 $\mathrm{m}$, with emergent trees reaching $30 \mathrm{~m}$, while the cloud dwarf forests have a canopy of about $10 \mathrm{~m}$, with few emergent trees, reaching up to $16 \mathrm{~m}$ (Olveira-Filho et al., 2013).

In general, the richness of the plant community of the cloud dwarf forests of ISP reinforces its importance for local, demonstrating that relatively small areas are also relevant for preservation and that even conservation units should improve strategies for maintaining biodiversity (Drummond et al. 2005).

\section{Phytogeography}

The studies that seek to understand the geographic distribution of the species present in the cloud dwarf forests are of fundamental importance, since they allow to subsidize strategies of conservation and environmental restoration, and help in the prediction of the impacts of future climate changes on the natural vegetation. In this study, we classified the genera in seven phytogeographic groups delimited based on their current centers of diversity cited in Safford (2007). Among the Austral-Antarctic genera, Drimys, Fuchsia, Polygala, and Weinmannia 
have few Atlantic representatives, whereas Myrceugenia is richer to the east of Brazil, with species indicative of the high montane forests under cold and humid climates (Meireles et al. 2008). These genera were part of a past flora dispersed among Australia, Antarctica, and South America (Brade 1956).

As representative of the Holartic floristic element, only the genus Rhamnus was found in the cloud dwarf forests of ISP. The presence of Holartic elements in the Neotropical flora has been associated with the proximity between North and South America during the Cretaceous, continental, and volcanic island arches in the Central American region, long-distance dispersal events during the Cenozoic, and the formation of the Isthmus of Panama and elevation of the northern Andes between the Miocene and the Pliocene, about 3.5 million years ago. According to Brade (1956), the Holartic element went from North America to South America using the mountain chain of the Andes as a migration bridge and later advanced to the east of the continent towards Serra da Mantiqueira and Serra do Mar.

According to Safford (2007), the flora of the Andes and the highest points of the Brazilian mountain ranges form a group of species tropical, temperate, and cosmopolitan origin that have developed in these places through long periods of environmental changes and migrations. Safford (2007) reports that during the drought periods of the Tertiary, the Atlantic mountain ranges served as a refuge for species adapted to cold and humidity, especially the Austral-Antarctic taxa, and that during long periods of colder weather a greater contact occurred between the plant formations of east and west of South America, thus favoring colonization of the tropical Atlantic forests by Andean elements. This contact may have occurred several times, and the Atlantic rainforests may have been an important source for the colonization of the new mountainous environments developed late in the northern Andes (Safford 2007).

In ISP, the temperate floristic component is represented by the genera Senecio and Dendrophorbium, whereas the cosmopolitan elements are represented by the genera Bidens, Borreria, Brickellia, Caamembeca, Cerastium, Commelina, Crepis, Ficus, Galactia, Ilex, Ipomoea, Malaxis, Oplismenus, Rhynchospora, Solanum, Setaria, Taraxacum, and Verbesina. Temperate taxa, mainly Holartics, are much more representative in the Andean flora than in the Brazilian mountains, due to a series of geographic and historical factors, lower altitudes, and the more limited area of the mountains in Brazil. Safford (2007) suggests that many temperate and cosmopolitan species first arrived in Southern Brazil by migrating through favorable habitats, rather than dispersing over long distances.

Among the ten endemic genera of Brazil, the family Gesneriaceae, represented by the Nematanthus and Vanhouttea, stands out. The genera Nematanthus is endemic in South and Southeastof Brazil, except for one species that reaches the south of Bahia (Chautems 1988). Vanhouttea has species distributed in the states of Espírito Santo, Minas Gerais and Rio de Janeiro (Chautems 2002). The other endemic genera are Eremanthus, Trembleya, Aosa, Dyssochroma, Gomesa (sensu stricto), Grobya, Periandra and Wittrockia, which present very common species in high altitude vegetation formations in the Atlantic Forest. Among these, Eremanthus, Periandra and Trembleya, present a greater richness in campos rupestres, with some species present in altitude fields and inside the cloud dwarf forestes (Giulietti \& Pirani 1988).

About $60 \%$ of the genera found are Neotropical, and among them, Cabralea, Leandra, Miconia, Mollinedia, Myrcia, Myrciaria, Roupala,
Siphoneugena, Pleroma, and Vernonanthura can present species of montane forests that tolerate adverse altitude conditions (Oliveira-Filho $\&$ Fontes 2000, Meireles et al. 2014). Among the Neotropical genera, some are commonly found in the Andes mountains, such as Baccharis and Chusquea, besides being of great importance in the floristic composition of the montane vegetation of the Southeastern and Southern Region of Brazil (Brade 1956, Safford 1999, Meireles et al. 2014).

The Hindsia genus is richest in the mountains of eastern Brazil, and in this study the species Hindsia ibitipocensis, considered to be endangered, is recorded only for a small part of the Serra da Mantiqueira, represented by ISP. (Di Maio 1996, Oliveira et al. 2013). Broad tropical genera accounted for $24 \%$, with predominance of the Asteraceae and Malvaceae families, in which attributes such as long dispersal distances, large fruit production, and seed dormancy are common, helping to increase their distributions (Lorenzi 2008).

Due to the historical process of land occupation, characterized mainly by the exploitation of timber species, forest fragmentation, and expansion of agricultural and livestock activities, the original forest areas of the Serra da Mantiqueira were drastically reduced (Almeida \& Carneiro 1998, Drummond et al. 2005). In this way, conservation of the remaining forests is fundamental, since besides presenting high residual diversity, they perform environmental services, such as the sequestration of atmospheric carbon dioxide, soil protection, maintenance of the hydrological cycle, and protection of watercourses (Pounds et al. 1999). It is important to point out that the cloud dwarf forests contribute with additional water provision to the water systems, through the capture of condensed water in the clouds. Therefore, conservation of these forests will contribute to the continuous production of water in the springs, which will benefit the production of drinking water and water quality for future generations (Oliveira-Filho et al. 2004). Further studies on the biodiversity of cloud dwarf forests are needed to support the development of public policies aimed at protecting these areas, especially given their great fragility in the face of global climate change (IPCC 2014).

\section{Acknowledgements}

We thank the employees of Ibitipoca State Park for their constant support throughout the project. We are also thankful for the great help provided by the students of the Graduate Program in Ecology (PGECOL) and the Plant Ecology Laboratory of the Federal University of Juiz de Fora (UFJF), during field activities and herbarium routines. Thanks also go to the researchers who helped in the botanical identification and to the UFJF for the support in the excursions to the study area. This work was supported by the Conselho Nacional de Desenvolvimento Científico e Tecnológico (CNPq) under grant 454008/2014-7 and Fundação de Apoio a Pesquisa do Estado de Minas Gerais (FAPEMIG) under grant APQ 2165/14.

\section{Author Contributions}

Breno Moreira: responsible for conception, field work, data analysis, identification of specimens and the writing manuscript.

Fabrício Alvim Carvalho: substantial contribution in analysis and interpretation of data and manuscript preparation. 
Luiz Menini Neto: substantial contribution in analysis and interpretation of data and manuscript preparation.

Fátima Regina Gonçalves Salimena: responsible for conception and coordinated the study.

\section{Conflicts of interest}

The authors declare that they have no conflict of interest related to the publication of this manuscript.

\section{References}

ALMEIDA, F.F.M. \& CARNEIRO, C.D. 1998. Origem e evolução da Serra do Mar. Revista Brasileira de Geociências 28: 135-150.

APG IV. 2016. An update of the Angiosperm Phylogeny Group classification for the orders and families of flowering plants: APG IV. Botanical Journal of the Linnean Society 181: 1-20.

ARCOVA, F.C.S. 2013. Avaliação do potencial hidrológico dos nevoeiros e da precipitação oculta em ambiente de Floresta Ombrófila Densa Montana na Serra do Mar, Cunha, SP. Tese De dorutorado, Universidade de São Paulo, São Paulo.

BENZING, D.H. 1998. Vulnerabilities of tropical forests to climate change: the significance of resident epiphytes. Climate Change 39, pp. 519-5440

BERTONCELLO, R., YAMAMOTO, K., MEIRELES, L.D. \& SHEPHERD, G.J. 2011. A phytogeographic analysis of cloud forests and other forest subtypes amidst the Atlantic forests in south and southeast Brazil. Biodiversity conservation 20(14): 3413-3433.

BFG. 2015. Growing knowledge: an overview of Seed Plant diversity in Brazil. Rodriguésia 66: 1085-1113.

BORGES, R.X.A., SAAVEDRA, M.M., NAKAJIMA, J.N. \& FORZZA. R.C 2010. The Asteraceae flora of the Serra do Ibitipoca: analyses of its diversity and distribution compared with selected areas in Brazilian mountain ranges. Systematics and Biodiversity 8(4): 471-479.

BRADE, A.C. 1956. A flora do Parque Nacional do Itatiaia. Boletim Parque Nacional do Itatiaia 5: 1-92.

BROWN, J.H., STEVENS, G.C. \& KAUFMAN, D.M. 1996. The geographic range: size, shape, boundaries, and internal structure. Annals Review of Ecology and Systematics 27: 597-623.

BRUIJNZEEL, L.A., SCATENA, F.N. \& HAMILTON, L.S. 2010. Tropical montane cloud forests: Science for conservation and management. Cambridge University Press, London, UK

BUBB, P., MAY, I., MILES, L. \& SAYER, J. 2004. Cloud forest agenda Cambridge: PNUMA-CMVC, $32 \mathrm{p}$.

CHAUTEMS, A. 1988. Revision taxonomique et possibilites d'hybridations de Nematanthus Schrader (Gesneriaceae), genre endemique de la forêt cotiere brésiliense. Dissertationes Botanicae 112:1-226.

CHAUTEMS, A. 2002. New Gesneriaceae from Minas Gerais, Brazil. Candollea 56: $261-270$

CORRÊA NETO, A.V. \& BAPTISTA FILHO, J. 1997. Espeleogênes em quartzitos da Serra do Ibitipoca, Sudeste de Minas Gerais. Anuário do Instituto de Geociências, Rio de Janeiro, v. 20, p. 75-87.

COSTA, C. \& HERRMANN, G. 2006. Plano de Ação do Corredor Ecológico da Mantiqueira. 1 ed. Valor Natural, 64p.

CRIA. Centro de Referência em Informação Ambiental. 2001. SpeciesLink. Disponível em $<$ http://splink. cria.org.br/tools?criaLANG=pt $>$ (último acesso 01/10/2017).

DIAS, H.C.T., FERNANDES FILHO, E.I., SCHAEFER, C.E.G.R., FONTES, L.E.F.F. \& VENTORIM, L.B. 2002. Geoambientes do Parque Estadual do Ibitipoca, município de Lima Duarte-MG. Revista Árvore 26(6): 777-786.

DI MAIO, F.R. 1996. Revisão taxonômica do gênero Hindsia Bentham (Rubiaceae, Hedyotideae). Arquivos do Jardim Botânico do Rio de Janeiro 34: 51-92.
DRUMMOND, G.M., MARTINS, C.S., MACHADO, A.B.M., SEBAIO, F.A. \& ANTONINI, Y. 2005. Biodiversidade em Minas Gerais, um atlas para sua conservação. Fundação Biodiversitas. Belo Horizonte.

EISENLOHR, P.V. \& OLIVEIRA-FILHO, A.T. 2015. Revisiting Patterns of Tree Species Composition and their Driving Forces in the Atlantic Forests of Southeastern Brazil. Biotropica 47: 689-701.

FALKENBERG, D.B. 2003. Matinhas nebulares e vegetação rupícola dos Aparados da Serra Geral (SC/RS), sul do Brazil. Tese de doutorado. Universidade Estadual de Campinas, Campinas.

FILGUEIRAS, T.S., NOGUEIRA, P.E., BROCHADO, A.L. \& GUALA, G.F. 1994. Caminhamento: um método expedito para levantamentos florísticos qualitativos. Cadernos de Geociências 12: 39-43.

FLORA DO BRASIL 2020. Em construção. Jardim Botânico do Rio de Janeiro. Disponível em: < http://floradobrasil.jbrj.gov.br/ > (último acesso 10/10/2017).

FONTES, M.A. 1997. Análise da composição florística das Florestas Nebulares do Parque Estadual do Ibitipoca, Minas Gerais. Dissertação de mestrado. Universidade Federal de Lavras, Lavras.

FRANÇA, G.S. \& STEHMANN, J.R. 2004. Composição florística e estrutura do componente arbóreo de uma floresta altimontana no município de Camanducaia, Minas Gerais, Brasil. Revista Brasileira de Botânica 27: 19-30.

FURTADO, S.G. 2016. Ecologia de epífitas vasculares nas Florestas Nebulares do Parque Estadual do Ibitipoca, Minas Gerais, Brasil. Dissertação de mestrado, Universidade Federal de Juiz de Fora, Juiz de Fora.

GIULIETTI, A.M. \& PIRANI, J.R. 1988. Patterns of geographic distribution of some species from the Espinhaco Range, Minas Gerais and Bahia, Brasil. In Proceedings of a Workshop on Neotropical Distribution Patterns (P.E. Vanzolini \& W.R. Heyer, eds.). Academia Brasileira de Ciências, Rio de Janeiro, p.39-69.

GONÇALVES, E.G. \& LORENZI, H. 2007. Morfologia vegetal: organografia e dicionário ilustrado de morfologia das plantas vasculares. São Paulo: Plantarum. 416p.

GRYTNES, J.A. \& MCCAIN, C.M. 2007. Elevational trends in biodiversity. Encyclopedia of biodiveristy.

HAMILTON, L.S., JUVIK, J.O. \& SCATENA, F.N. 1995. The Puerto Rico tropical cloud forests symposium: introduction and workshop synthesis. In Tropical montane cloud forests (L. S. Hamilton, J. O. Juvik \& F. N. Scatena, eds.). Springer-Verlag, New York, p.1-23.

INTERGOVERNMENTAL PANEL ON CLIMATE CHANGE - IPCC 2014 Climate Change 2014: Impacts, Adaptation and Vulnerability “ (IPCC). Work Group 2. Genebra. 2014. IPCC 2014 Fifth Assessment Report. Disponível em: <http://www.ipcc-wg2.gov/AR5/> (último acesso 01/10/2017).

JUDD, W.S., CAMPBELL, C.S., KELLOGG, E.A., STEVENS, P.F. \& DONOGHUE, M. J. 2009. Sistemática Vegetal: Um enfoque filogenético. Porto Alegre: Artmed. 632p.

KÖPPEN, W. 1948. Das geographische System der Klimate - handbuch der klimatologie. Vol. 1. Part C. Berlim: Gebr. Bornträger Verlag, 388 p.

KÖRNER, C. 1999. Alpine Plant Life: functional plant ecology of high mountain ecosystems. Springer-Verlag, Berlim, Heidelberg.

LORENZI, H. 2008. Árvores brasileiras: manual de identificação e cultivo de plantas arbóreas nativas do Brasil. 5.ed. Nova Odessa: Instituto Plantarum, v.1. $368 \mathrm{p}$

MARTINELLI, G. 2007. Mountain biodiversity in Brazil. Revista Brasileira de Botânica 30(4): 587-597.

MARTINELLI, G. \& MORAES, M.A. 2013. Livro vermelho da flora do Brasil. Jardim Botânico do Rio de Janeiro. http://cncflora.jbrj.gov.br (último acesso 01/10/2017)

MARTINS-RAMOS, D., CHAVES, C.L., BORTOLUZZI, R.L.C. \& MANTOVANI, A. 2011. Florística de floresta ombrófila mista alto-montana e de campos em Urupema, Santa Catarina. Brasil. Revista Brasileira de Biociências. 9(2): 156-166.

MBG. Missouri Botanical Garden. 2014. Tropicos.org. Disponível em $<\mathrm{http}: /$ www.biologie.uni-hamburg. de/b-online/ibc99/mobot/pick.html> (último acesso 10/10/2017). 
MEIRELES, L.D., SHEPHERD, G.J. \& KINOSHITA, L.S. 2008. Variações na composição florística e na estrutura fitossociológica de uma floresta ombrófila densa alto-montana na Serra da Mantiqueira, Monte Verde, MG. Revista Brasileira de Botânica 31: 559-574.

MEIRELES, L.D., KINOSHITA, L.S. \& SHEPHERD, G.J. 2014. Composição florística da vegetação altimontana do distrito de Monte Verde (Camanducaia, MG), Serra da Mantiqueira Meridional, Sudeste do Brasil. Rodriguésia 65: 831-859.

MENINO, G.C.O. 2013. Dinâmica da comunidade arbórea de uma floresta nebular na Serra de Ibitipoca, Minas Gerais. Tese de Doutorado Universidade Federal de Lavras, Lavras.

MOCOCHINSKI, A.Y. \& SCHEER, M.B. 2008. Campos de altitude na Serra Paranaense: aspectos florísticos. Floresta 38: 625-640.

MOREIRA, A.A.N. \& CAMELIER, C. 1977. Relevo. In Geografia do Brasil. Fundação Instituto Brasileiro de Geografia e Estatística, Rio de Janeiro, v.3, p.1-150.

MORI, S.A., SILVA, L.A.M., LISBOA, G. \& CORADIN, L. 1989. Manual de manejo de herbário fanerogâmico. Ilhéus, BA: Centro de Pesquisas do Cacau.

NUMMER, A.R. 1991. Mapeamento geológico e tectônico experimental do grupo Andrelândia na região de Santa Rita do Ibitipoca - Lima Duarte, Sul de Minas Gerais. Dissertação de Mestrado. Universidade Federal do Rio de Janeiro, Rio de Janeiro.

OLIVEIRA, J.A., SALIMENA, R.F.G. \& ZAPPI, D. 2014. Rubiaceae da Serra Negra, Minas Gerais, Brasil. Rodriguésia [online]. 65(2): 471-504.

OLIVEIRA-FILHO, A.T. \& FONTES, M.A.L. 2000. Patterns of floristic differentiation among Atlantic Forests in Southeastern Brazil and the influence of climate. Biotropica 32(4): 793-810.

OLIVEIRA-FILHO, A.T., CARVALHO, D.A., FONTES, M.A.L., VAN DEN BERG, E., CURI, N. \& CARVALHO, W.A.C. 2004. Variações estruturais do compartimento arbóreo de uma floresta semidecídua alto-montana na chapada das Perdizes, Carrancas, MG. Revista Brasileira de Botânica 27(2): 291- 309

OLIVEIRA-FILHO, A.T., JARENKOW, J.A. \& RODAL, M.J.N. 2005. Floristic relationships of seasonally dry forests of eastern South America based on tree species distribution patterns. In: PENNINGTON, R. T. et al. (Ed.). Neotropical savannas and dry forests: plant diversity, biogeograpgy and conservation. Boca Raton: CRC Press, p.151-184.

OLIVEIRA-FILHO, A.T. 2009. Classificação das fitofisionomias da América do Sul cisandina tropical e subtropical: proposta de um novo sistema - prático e flexível - ou uma injeção a mais de caos. Rodriguésia 60: 237-258

OLIVEIRA-FILHO, A.T., FONTES, M.A.L., VIANA, P.L., VALENTE, A.S.M., SALIMENA, F.R.G. \& FERREIRA, F.M. 2013. O mosaico de fitofisionomias do Parque Estadual do Ibitipoca. In Flora do Parque Estadual do Ibitipoca e seu entorno. 1 ed. Juiz de Fora, 384p.

PEREIRA-SILVA, E.F.L., HARDT, E. \& FRANCISCO, C.E.S. 2007. Caracterização florística da vegetação lenhosa de um fragmento urbano de Floresta Ombrófila Mista Alto Montana, Campos do Jordão, SP. Holos Environment 7(2):154-170.

PEREIRA, I.A., OLIVEIRA-FILHO, A.T., BOTELHO, S.A., CARVALHO, W.A.C., FONTES, M.A.L., SCHIAVINI, I. \& SILVA, A.F. 2006. Composição florística do compartimento arbóreo de cinco remanescentes florestais do maciço do Itatiaia, Minas Gerais e Rio de Janeiro. Rodriguésia 57(1): 103-126.
PILLAR, V.D., MÜLLER, S.C., CASTILHOS, Z. \& JACQUES, A.V.A. (Orgs.). 2009. Campos Sulinos: conservação e uso sustentável da biodiversidade. Brasília: Ministério do Meio Ambiente. 403p.

POMPEU, P.V., FONTES, M.A.L., SANTOS, R.M., GARCIA, P.O., BATISTA, T. A. \& CARVALHO, W.A.C.; OLIVEIRA-FILHO, A.T. 2014. Floristic composition and structure of an upper montane cloud forest in the Serra da Mantiqueira Mountain Range of Brazil. Acta Botanica Brasilica 28:456-464.

POUNDS, A., FOGDEN, M.P.L \& CAMPBELL J.H. 1999 Biological response to climate change on a tropical mountain. Nature 398:611-615.

RAHBEK, C. 2005. Thee role of spatial scale and the perception of large-scale species - richness patterns. EcologyLetters 8(2):224-239.

RICHARDSON, B.A, RICHARDSON, M.J., SCATENA, F.N. \& MCDOWELL W.H. 2000. Effects of nutrient availability and other elevational changes on bromeliad populations and their invertebrate communities in a humid tropical forest in Puerto Rico J. Tropical Ecology 16: 167-188.

RODELA, L. G. \& TARIFA, J. R. 2002. Clima da Serra do Ibitipoca, sudeste de Minas Gerais. Geousp: Espaço e Tempo 11: 101-113.

SAFFORD, H.D. 1999. Brazilian Páramos I. An introduction to the physical environment and vegetation of the campos de altitude. Journal of Biogeography 26(4): 693-712.

SAFFORD, H.D. 2007. Brazilian Páramos IV. Phytogeography of the campos de altitude. Journal of Biogeography 34: 1701-1722.

SALIMENA, F.R.G., MATOZINHOS, C.N., ABREU, N.L., RIBEIRO, J.H.C. SOUZA, F.S. \& MENINI-NETO, L. 2013. Flora fanerogâmica da Serra Negra, Minas Gerais, Brasil. Rodriguésia 64(2): 311-320.

SANTIAGO, D.S., OLIVEIRA-FILHO, A.T., MENINI NETO, L., CARVALHO, F.A. \& SALIMENA, F.R.G. 2018. Floristic composition and phytogeography of an Araucaria Forest in the Serra da Mantiqueira, Minas Gerais, Brazil. Rodriguésia 69 (no prelo).

SCHEER, M.B. \& MOCOCHINSKI, A.Y. 2009. Florística vascular da Floresta Ombrófila Densa Altomontana de quatro serras no Paraná. Biota Neotropica 9(2):51-70.

SLIK, J.W., SHIN-ICHIRO, A.S.I., BREARLEY, F.Q., CANNON, C.H., FORSHED, O. \& KITAYAMA, K. 2010. Environmental correlates of tree biomass, basal area, wood specific gravity and stem density gradients in Borneo's tropical forests. Global Ecology and Biogeography 19:50-60.

TEIXEIRA, W. \& CORDANI, G. 2007. Caminhos do Tempo Geológico In Itatiaia: Sentinela das Alturas (W. Teixeira \& R. Linsker, coords) Terra Virgem, São Paulo, p. 28-62.

THIERS, B. 2016 [continuously updated]. In: Index Herbariorum: A global directory of public herbaria and associated staff. New York Botanical Garden's Virtual Herbarium.

VALENTE, A.S.M., GARCIA, P.O., SALIMENA, F.R.G. \& OLIVEIRA-FILHO, A.T. 2011. Composição, estrutura e similaridade florística da Floresta Atlântica, na Serra Negra, Rio Preto, Minas Gerais, Brasil. Rodriguésia 62(2): 321-340.

VÁZQUEZ-GARCÍA, J.A. 1995. Cloud forest archipelagos: preservation of fragmented montane ecosystems in tropical America. Pp. 315-332 in L.S. Hamilton, J.O. Juvick, and F.N. Scatena, eds., Tropical Montane Cloud Forest. Ecological Studies, no. 110. Springer Verlag, New York.

WEBSTER, G.L. 1995. The panorama of Neotropical Cloud Forests. In: Churchill, S. P.; Balslev, H.; Forero, E. \& Luteyn, J. L.(eds.). Biodiversity and Conservation of Neotropical Montane Forests: Proceedings of Neotropical Montane Forest Biodiversity and Conservation Symposium. The New York Botanical Garden, New York. Pp. 53-77. 